\title{
AKAR KEKERASAN TERHADAP PEREMPUAN DALAM FIQH AL-NISA'
}

Tutik Hamidah, M.Ag. Ka. Prog. Syari' ah STAIN Malang

Tutik Hamidah, M.Ag. Lahir di Lamongan, 23 April 1959. Telah menyelesaikan S2 di IAIN Sunan Kalijaga dengan spesifikasi bidang Fiqh. Kini sebagai Kepala Program Syari'ah dan dosen tetap STAIN Malang bidang studi yang diajarkan adalah Fiqh. Aktif mengisi forum-forum kajian, seminar atau dialog dalam pemikiran hukum Islam. Juga aktif untuk menulis artikel ilmiah pada majalah dan jumal. Melakukan penelitian baik individu maupun kelompok.
Kekerasan dalam Analisis Gender.

Benarkah ada kekerasan terhadap perempuan? Pada umumnya masyarakat kurang percaya atau bahkan tidak percaya atau menganggap bahwa kekerasan itu merupakan kewajaran, bukan suatu kekerasan. Terhadap pertanyaan di atas, biasanya muncul pertanyaan lanjutannya, bukankah laki-laki juga sering mengalami kekerasan? Mengapa terlalu menonjolkan kekerasan terhadap perempuan?

Memang, kekerasan bisa terjadi pada perempuan dan lakilaki secara bersamaan. Akan tetapi, jika dianalisis dari sudut pandang pola hubungan laki-laki dan perempuan, akan terlihat bahwa kekerasan terhadap perempuan menjadi lebih kompleks dan meluas, akibat pola hubungan laki-laki dan perempuan tersebut. Analisis yang mempertanyakan pola hubungan lakilaki dan perempuan tersebut, disebut analisis gender.(Mansour Fakih,1996,3-12)

Di dalam analisis gender, hal pertama yang harus difahami adalah perbedaan kata sex dan gender. Secara singkat bisa dikatakan, sex adalah "jenis kelamin biologis" yang dibedakan menjadi laki-laki dan perempuan, karena adanya perbedaan fa'ali biologis antara keduanya. Perbedaan ini disebut kodrat, tidak bisa berubah. Misalnya, laki-laki memiliki penis, jakala, tidak memiliki indung telur dan sebagainya, sedangkan perempuan memiliki payudara, rahim, vagina dan lain sebagainya. Gender adalah pembedaan karakteristik dan peran sosial laki-laki dan perempuan yang dihubungkan atas jenis kelamin (sex). Karakteristik dan peran sosial itu merupakan hasil konstruksi sosial atau kultural, bukan kodrat. Karenanya, gender sering disebut "jenis kelamin sosial". Misalnya, sifat yang dilekatkan pada perempuan adalah lemah lembut, pesolek, emosional, pasif. Laki-laki itu kuat, agresif, aktif, rasional, tangguh.(Rifka Annisa,1998,5) Pembedaan tersebut, -walaupun tidak bisa dikatakan benar, karena o@fcit fta tidak bisa digeneralisir-adalah wajar saja, seandainya tidak berimplikasi pada terjadinya ketidakadilan atau bahkan kekerasan. (Mansour Fakih,1996,1223) Pembedaan karakteritik atau stereotype tersebut, akhirnya 
Dalam banyak kasus, suami yang tidak mampu mengaktualisasikan stereotype itu merasa tertekan, dan tidak jarang melampiaskannya dalam bentuk mengontrol, menguasai ataupun bertindak keras terhadap istri. mengantarkan pada pembedaan peran sosial laki-laki perempuan. Contoh yang mudah diidentifikasi adalah pembakuan tugas suami istri, suami adalah kepala keluarga, pencari nafkah dan harus mengambil peranan di wilayah publik, seperti pemimpin masyarakat; sedangkan istri adalah ibu rumahtangga berkewajiban mengatur, membersihkan rumahtangga, menyiapkan makanan, mendidik anak dan jika mencari nafkah, maka ia diposisikan sebagai pencari nafkah tambahan. Pada akhimya, secara sosial laki-laki dikondisikan untuk tumbuh dan berkembang dengan perspektif sebagai "pemimpin". Oleh sebab itu mereka dikondisikan dengan stimulasi sosial-psikologis yang bertujuan memunculkan berbagai potensi pribadi yang mendukung kualifikasi seorang pemimpin. Demikian juga dengan perempuan, stimulasi lebih ditujukan untuk memunculkan potensi mereka yang berkaitan dengan peran sebagai lbu rumah tangga. Plotting peran ini menyebabkan perlakuan diskriminatif terhadap perempuan, sekaligus dalam beberapa hal juga merugikan laki-laki.

Bagaimana hal itu bisa merugikan laki-laki ? Coba simak, dalam kenyataan, berapa banyak laki-laki yang mampu mewujudkan stereotype itu ? Menjadi pemimpin, rasional, mengetahui seluruh persoalan, tak pernah laridari pertanungan, karimya sukses dan menghasilkan uang banyak. Sungguh tidak banyak. Akan tetapi masyarakat selalu terdorong untuk mengingat stereotype itu. Dalam banyak kasus, suami yang tidak mampu mengaktualisasikan stereotype itu merasa tertekan, dan tidak jarang melampiaskannya dalam bentuk mengontrol, menguasai ataupun bertindak keras terhadap istri.(Rifka Annisa, 1997,16)

Pembakuan tugas suami istri, seperti yang disebut diatas, juga mendorong terjadinya relasi yang timpango yang tidak setara antara suami istri. Suami dilatih untuk merasa berkuasa atas orang-orang di sekelilingnya, istri dilatih untuk patuh. Dalam kondisi seQert:L i-ni-, menjadi merasa mempunyai hak paten untuk bersikap seperti

“Bos" terhadap istri. Ironinya, masyarakat menganggapnya sebagai kewajaran bahkan kebaikan.

Demikianlah sekilas analisis gender, yang mennjukkan adanya suatu bentuk ketidakadilan yang berakar pada stereo- 
type laki-laki perempuan serta pola relasi laki-laki perempuan yang dilembagakan masyarakat. Teori ini relatif masih baru dan masih sulit diterima masyarakat. Pada umumnya ketika pola relasi laki-laki dan perempuan ini dipertanyakan, maka segera kita dicap sebagai mengingkari kodrat. Padahal, hal itu tidak berarti bahwa kaum perempuan merasa rendah sebagai Ibu rumahtangga. Sama sekali tidak. Akan tetapi yang diinginkan adalah diwariskan secara turun temurun, yang memang merugikan baik laki-laki dan terutama perempuan. Dengan kata lain, apakah perempuan menjadi Ibu rumahtangga saja atau berprofesi di luar rumah, hal itu seharusnya dilakukan atas kesadarannya terhadap kewajiban-kewajiban dasariyah dan hak-hak dasariyah manusia. Tidak melulu didesak, ditekankan bahwa tugas utamanya adalah sebagai Ibu rumahtangga dengan tugas-tugas kerja ruinahtangga, yang pada hakekatnya pekerjaan rumahtangga itu bisa dipertukarkan (changable) antara suami istri.

Perempuan dalam Figh al-Nisa'

Pada umumnya disepakati bahwa core keislaman adalah ilmu figh. Dalam probleinatika keperempuanan, ilmu figh memiliki peranan sangat besar, karena ilinu fiqh-lah yang menstrukturkan hubungan laki-laki pereinpuan. Dalam konteks ini, penulis hanya membahas fiqh perempuan dalam keluarga. Sebagai sumber bahasan, penulis menggunakan kitab Fiqh alSuniiah karya Sayyid Sabiq, karena kitab tersebut samopai saat ini tercatat sebagai referensi wajib.dalam mata kuliah figh di buku Kurikulum IAIN maupun STAIN.

Sayid Sabiq menjelaskan hak dan kewajiban suami halaman 134-180, dengan membaginya menjadi tiga kategori

1. Hak-hak istri berarti kewajiban suami

2. Hak-hak suami berarti kewajiban istri

3. Hak-hak bersama antara suami istri berarti kewajiban bersama antara suami istri.

Terhadap hak-hak tersebut, Sabiq menjelaskan, masingmasing pihak, suami istri, harus melaksanakan kewajibankewajibannya, agar kehidupan keluarga memperoleh ketenangan, kedamaian dan kebahagiaan.

Selanjutnya, keseluruhan uraian Sabiq tentang hak dan
Dalam problematika keperempuanan, ilmu fiqh memiliki peranan sangat besar, karena ilmu figh-lah yang menstrukturkan hubungan laki-laki perempuan 
kewajiban suami istri, dengan menggunakan analisis gender, dapat disimpulkan sebagai berikut

Istri sebagai obyek

Hal ini terlihat dalam hak-hak istri berarti kewajiban suami maupun hak-hak suami berarti kewajiban istri. Secara garis besar bisa disebutkan sebagai berikut

1. Kewajiban memberi mahar dan nafkah kepada istri yang mirip pembayaran harga dalam perdagangan. Suami wajib memberi mahar dan nafkah kepada istri.jika sudah mempergauli istri. Jika belurfl mempergauli, maka tidak wajib memberi nafkah, walaupun sudah terjadi akad nikah.(Sayid Sabiq,1982,jilid II,148)

2. Sebagai obyek, istri hanya berhak diberi nafkah sekedar mencukupi kebutuhannya, yang dirinci meliputi kebutuhan makan, minum, buah dan pakaian yang boleh diberikan dalam bentuk barangnya maupun harganya. Istri tidak boleh menuntut lebih dari yang dianggap cukup suaminya. (Sayid Sabiq,1982,jilid II,151-153)

3. Kewajiban memberi nafkah itu disebabkan, sesudah menikah, istri ibarat orang dipenjara. (Sayid Sabiq,1982, jilid II,148) Istri tidak boleh melakukan aktivitas-aktivitas yang dapat menyebabkan tidak terpenuhinya hak-hak suami, terutama hak-hak yang berkaitan dengan pemeniihan hasrat seksual. Sabiq mengutip sebuah hadis, bahwa siapa saja istri yang menolak ajakan bersetubuli suarninya, lalu suamipun kecewa, maka atas istri kutukan malaikat sampai

Sabiq mengutip sebuah hadis, bahwa siapa saja istri yang menolak ajakan bersetubuli suarninya, lalu suamipun kecewa, maka atas istri kutukan malaikat sampai pagi hari tiba pagi hari tiba.(Sayid Sabiq,1982,jilid II,173) Betapa mengerikannya! Bahkan hasrat seksual suamipun dijustifikasi dengan laknat malaikat. Untuk itu istri tidak boleh melakukan anjuran-anjuran agama sekalipun, seperti puasa hari Senin dan Kamis, salat di masjid, kelijar rumah, tanpa seizin suami. Sabiq mengutip sebuah hadis, "Seandainya aku (Rasul saw) memerintahkan seseorang bersujud kepada manusia, tentu aku peritahkan istri sujud kepada suami, karena begitu besarnya hak suami terhadap istri'.(Sayid Sabiq, 1982,jilid II,172).

4. Sebagai obyek, istri tidak mempunyai hak atas seksualitas miliknya sendiri. Sebagaimana hadis yang disebutkan 
diatas, kapanpun suami menghendaki, ia harus memenuhinya. Sebaliknya, walaupun disebutkan bahwa suami berkewajiban mempergauli istri; tetapi Tonggar. Sabiq mengutip beberapa pendapat, ada yang minimal satu kali pada setiap masa suci, ada yang enam bulan sekali, satu kali dalam ernpat hari, bahkan ada yang berpendapat bahwa hasrat seksual adalah hak suami, karenanya suami bebas untuk inenggunakan hak itu atau tidak. (Sayid sabiq,1982.jilid II, 163)

Istri harus mengerjakan pekerjaan-pekerjaan rumahtangga Berbeda dengan pendapat yang dikemukakan dalam mazhab Maliki, Hanafi dan Syafil, yang tidak mewajibkan istri melakukan pekerjaan-pekerjaan rumahtangga, seperti memasak, membersihkan rumah, mencuci, mendidik anak dan sebagainya, Sabiq berpendapat bahwa istri wajib mengerjakan pekerjaanpekerjaan rumah tangga.(Sayid Sabiq,1982.jilid II,174) Menurut mazhab-mazhab tersebut kewajiban istri hanyalah menyenangkan suami saia, seluruh beban rumahtangga, sampai menyusui anak adalah merupakan kewajiban suami.(Sayid Sabiq,1982,jilid II,175-6)

Dalam hal ini Sabiq mengemukakan, bahwa Islam mengatur hubungan suami istri dengan asas fitrah dan naluri. Laki-laki lebih mampu bekerja dan berusaha diluar rumah, sedang istri lebih mampii mengatur dan menghias rumah, mendidik anak dan sebagainya. Karena itu, suami wajib memberi nafkah sedang istri wajib mengerjakan pekerjaan-pekerjaan rumah. Ia mengutip surat

hak yang sebanding dengan kewajibannya dengan cara yang baik. Akan tetapi para suami memiliki derajat yang lebih tinggi dari pada istri".

Ketentuan ini mengukuhkan bahwa perempuan adalah makhluk domestik, yang harus selalu tinggal di rumah suaminya (Sabiq menggunakan kata mahbusat, terpenjara atau dipenjara). Ia tidak boleh melakukan aktivitas di luar rumah, baik untuk kepentingan ekonomi, sosial, mencari ilmu, ibadah ritual, kecuali atas seizin suaminya.

Suami dibenarkan memukul istri

Sabiq mengutip surat al-Nisa' ayat 34 , "Wanita wanita yang kamu hawatiri|nusyuznya, maka nasehatilah mereka dan
Ketentuan ini

mengukuhkan bahwa perempuan adalah makhluk domestik, yang hanus selalu tinggal di numah suaminya (Sabiq menggunakan kata mahbusat; terpenjara atau dipenjara). Ia tidak boleh melakukan aktivitas di luar numah, baik untuk kepentingan ekonomi, sosial, mencari ilmu, ibadah ritual, kecuali atas seizin suaminya. 
Dan bergaullah dengan mereka secara patut. Kemudian bila kamu tidak menyukai mereka, (maka bersabarlah) karena mungkin kamu tidak menyukai sesuatu, padahal Allah menjadikan padanya kebaikan yang banyak pisahkanlah diri dari tempat tidur mereka, dan pukullah mereka. Kemudian jika mereka mentaatimu, maka janganlah kamu mencari-cari jalan untuk menyusahkannya". Nusyuz adalah ketidaktaatan istri kepada suaminya. Misalnya, tidak memenuhi hasrat seksual suami atau keluar rumah tanpa seizin suami. Berdasarkan ayat diatas, maka istri harus diperingatkan terlebih dulu, jika peringatan itu belum merighentikan nusyuznya, maka berpisah tempat tidur, jika masih belum menghentikannya, maka boleli memukul di tempat-tempat selain wajah dan tempat yang membahayakan.(Sayid Sabiq,1982,jilid II,179)

Sekali lagi, ketentuan ini jelas untuk kepentingan suami sebagai subyek dalam keluarga.

Kedudukan Istri sejajar dengan suami.

Meskipun secara garis besarnya, fiqh memposisikan istri sebagai obyek, namun dalam beberapa hal istri diposisikan sejajar dengan suami. Hal ini dalam ketentuan tentang hak bersama antara suami istri. Ketentuan tersebut meliputi, halalnya hubiingan suami istri serta menikmati hubungan tersebut; hak waris antara keduanya; menjadi muhrimriya hubiingan persemendaan; nasab anak dari suaminya; pergaulan antara suami istri dengan cara yang baik.

Sabiq menjelaskan bahwa suami berkewajiban memuliakan istrinya, mempergauli dengan cara yang baik dan menyenangkan hatinya serta bersikap sabar terhadap perilaku istri yang tidak disukai. Ia mengutip surat alNisa' ayat 19, "Dan bergaullah dengan mereka secara patut. Kemudian bila kamu tidak menyukai mereka, (maka bersabarlah) karena mungkin kamu tidak menyukai sesuatu, padahal Allah menjadikan padanya kebaikan yang banyak". Dan menguatkannya dengan mengutip hadis, "Tidak memuliakan istri kecuali orang yang mulia dan tidak merendahkan istri kecuali orang yang tercela" . (Sayid Sabiq,1982,jilid II,160).

\section{Bentuk-bentuk kekerasan}

Uraian tentang perempuan dalam keluarga yang dikutipdengan kajian tentang kekerasan terhadap perempuan yang berkembang akhir-akhir ini, maka ditemukan berbagai macam bentuk kekerasan. 
1. Kekerasan fisik. Dengan dilegalkannya memukul karena ketidaktaatan istri kepada suami. $\mathrm{Hal}$ imi bertentangan dengan cinta kasih sebagai landasan membangun rumah tangga yang bahagia. Memukul adalah kekerasan dan kekerasan tentu kontra produktif dengan cinta. Akibat dari kekerasan itu, mungkin akan sangat lama dan dalam. Secara diam-diam dan mungkin tidak disadari perasaan istri menjadi hambar, dia merasa tidak memiliki harga diri, cemas, yang biasanya semuanya ditanggungnya sendiri, ditutupnya dengan kebisuannya.

2. Kekerasan ekonomi. Deiigan mengisolasi istri dengan pekerjaan-pekerjaan rumahtangga, tidak boleh keluar rumah dengan tujiian apapun keciiali jika suaminya mengizinkan, padahal dalam konsep fiqh diatas, tidak ada konsep harta bersama, sehingga jika istri menggunakan harta, harus pula seizın suaminya.

3. Kekerasan seksual. Karena kewajiban memenuhi hasrat seksual suami adalah kewajiban yang sangat ditekankan dalam fiqh. Tidak ada ruang bagi istri untuk menolak, dan jika terpaksa, suami boleh memukul karena penolakan itii.

4. Kekerasan psychologis. Dalam uraian fiqh diatas, tidak psychologfs. Suami harus mempergauli dengan perkataan dan sikap yang baik kepada istri. Walaupuii kehariisan ini tidak diungkapkan dengan cara yang ekstrim, seperti, seandainya boleh bersujud kepada manusia, dia harus suiud kepada istri, sebagaimai-ia ungkapan dalam keharusan istri berbuat baik kepada suaminya.

\section{Penutup}

Seberapa besarkah kekerasan terhadap perempuan yang berakar pada Fiqh al-Nisa'? Boleh jadi sangat besar. Akan tetapi, tentu tidak fair menghakimi Fiqh al-Nisa' dengan konteks sekarang. Bagaimanapun fiqh adalah produk zamannya. Bahwa pada umumnya dalam Fiqh al-Nisa', perempuan diposisikan sebagai the secoi2 $\mathrm{d}$ sex, pemeran kedua atau obyek adalah karena beberapa faktor. Pertama, beberapa ayat al-Qur'an dan hadis Nabi saw memang menghadirkan nuansa patriarkhi, suatu pandangan yang menempatkan laki-laki sebagai superior dan
Memukul adalah

kekerasan dan kekerasan tentu kontra produktif dengan cinta. Akibat dari kekerasan itu, mungkin akan sangat lama dan dalam. Secara diam-diam dan mungkin tidak disadari perasaan istri menjadi hambar, dia merasa tidak memiliki harga diri, cemas, yang biasanya semuanya ditanggungnya sendiri, ditutupnya dengan kebisuannya. 
Yang disebut

Hukum Islam seharusnya, adalah hiikiim yang selalu diberi ruang untuk

menyegarkan dirinya sendiri (Abdurrahman Wachid, 1997, xiii) . Mungkin diantara kita ada yang tidak sependapat dengan pernyataan diatas. Akan tetapi, bukankah sebuah diskusi, bahkan mazhab, lahir karena adanya perbedaan pendapat? perempuan inferior. Kedua, setting kesejarahan fiqh itu pada umumnya adalah wilayah Timur tengah yang memang sangat patriarkhi dan ketiga, penulis fiqh itu adalah laki-laki yang tentu lebih mempresentasikan superioritas laki-laki.

Jika demikian, pertanyaan kita adalah, apakah kita berhak membai-igiin vision zamaii kita sendiri ? Berhakkah kita meredef inis i muasyarah bi al -ma '.ruf dengan zaman kita, yaitu melawan pandangan patriarkhi dan ketidak setaraan gender, yang menyebabkan ketidakadilan bahkan kekerasan pada perempuan? Menjawab pertanyaan ini, penulis meminjam pernyataan Amir Syarifuddin, "Tidak seyogyanya kita menggugat fiqh sebagai sesuatu yang kaku dan tidak kontekstual. Fiqh adalah hasil ijtihad miijtahid yang sangat baik, relevan, dinamis pada zamannya. Yang kakii adalah pemikiran untuk menggunakan karya lama itu untuk tata aturan keagamaan masa kini yang kaku ialah usaha menyusun fiqh baru namun tetap berpijak pada sistem metodologi dan prinsip dasar yang digunakan dalam merancang $f$ iqh yang lama" . (Amir Syarifuddin,1993,77) Senada dengan Syarifuddin, Abdurrahman Wachid menyatakan, "Yang disebut Hukum Islam seharusnya, adalah hiikiim yang selalu diberi ruang untuk menyegarkan dirinya sendiri (Abdurrahman Wachid, 1997, xiii) . Mungkin diantara kita ada yang tidak sependapat dengan pernyataan diatas. Akan tetapi, bukankah sebuah diskusi, bahkan mazhab, lahir karena adanya perbedaan pendapat?

\section{DAFTAR PUSTAKA}

Abdurrahman Wachid, "Pengantar" dalam Dr. MA alBayaniini, Memahami Hakekat Hukum Islam, Jakarta, Pustaka Firdaus, 1997.

Amir Syarifuddin, Prof.Dr., Pembaharuai2 Pemikiran dalam ï'ak'uin i-s-[am, Flacfang, Angkasa Raya,1993.

Rifka Annisa Women's Crisis Center, Bei2arkah Kita Mencintal Istri Kita ?, Yogyakarta, 1998.

Sayyid Sabiq, Fiqh a/Szjnnah, jilid II, Kairo, Dar alFikr,1982.

Kalau misalnya Tuhan menjadikan wanita dan pria itu 